\title{
Idrottens historie
}

\author{
Af Jan Linroth og K. Arne Blom \\ Stockholm 1995
}

Idrottens historie har som målgruppe et idrætshistorisk interesseret publikum, og det anføres, at den kan anvendes som lærebog. Det anføres ikke direkte, om det er på gymnasie- eller universitetsniveau. Umiddelbart vil jeg anslå, at den ville kunne benyttes på begge niveauer. I Danmark synes selve ideen om at skrive lærebøger i de humanistiske og sociologiske områder at være totalt opgivet for mange år siden. I Danmark har den danske oversættelse og bearbejdning af $\mathrm{K}$. Heinemans lærebog i idrætssociologi fået en blandet historie. Det er svært at skrive lærebøger, og det er svært at bruge dem. Det er derfor prisværdigt, at Linroth og Blom har taget dette initiativ.

Det er ikke en bog om svensk idrætshistorie i snæver forstand. Sverige fylder godt og vel halvdelen. Der er ikke meget om de $\varnothing v$ rige skandinaviske lande. Det er en bog om idrætshistorien. Hovedvægten ligger på Europa og USA, men også andre ikke-europæiske kulturers idræt er inddraget. Idrætslig kulturel kommunikation (import og eksport) har fået sit eget kapitel til sidst i bogen.

Idrættens historie har en betydelig vægt på svensk idrætshitorie, men sætter den konsekvent ind i en historisk og international sammenhæng.

Bogen er en nøgtern og forsigtig skildring af den svenske idrætshistorie, der omhyggeligt påpeger, hvad man faktisk ved og ikke ved. Den er noget mindre for- sigtig i sine vurderinger af den internationale situation.

Denne nøgternhed gør den anvendelig til at udpege kommende forskningsområder vedrørende Sverige og sammenligninger med det $\varnothing v$ rige Norden og Europa. Kapitlerne om den internationale udvikling egner sig mere til en debat.

For danske idrætsforskere og idrætsinteresserede frembyder bogen en kærkommen oversigt over den svenske idrætshistorie og især over den svenske gymnastikhistorie. Dansk og svensk gymnastikhistorie er flere steder i det historiske forløb flettet sammen, selvom der er tale om endog meget forskelligartede sammenhænge, som gymnastikken indgår i. Ling og Nachtegall i Danmark, Linggymnastikkens introduktion i DK, først gennem private institutter, siden gennem Højskolen.

I Danmark fik vi flere selvstændige idrætsorganisationer, og vi har stadigvæk tre. I Sverige stod kampen fra århundredeskiftet mellem Centralforeningen, der stod for et lingiansk syn på gymnastikken og idrætten, og Rigsidrætsforbundet der organiserede sporten. I begyndelsen af 30'rne fusionerede de to organsationer, og gymnastikken blev til et specialforbund. Der er i bogen stof til eftertanke med hensyn til organisationsspørgsmålet i en komparativ sammenhæng. Meget synes at afhænge af gymnastikkens udvikling og forankring. I Danmark fik gymnastikken en fast forankring i et landbomiljø med højskolen som 
avantgarde. Samtidig var den svenske og svenskinspirerede gymnastik istand til at forny sig. Derfor kunne gymnastikken hævde sin stilling. Det var spørgsmålet om gymnastikken, der førte til seperatistbevægelser i de Danske Skytteforeninger efter slutningen af første verdenskrig. Det var gymnastikken, der førte til sprængningen i 1929 og dannelsen af DDG. I Sverige var gymnastikken spændt fast i lingiansk ortodoksi og i Centralforeningens elitære struktur. Resultatet blev i Sverige en enhedsorganisation med gymnastikken som et specialforbund. Resultatet blev i Danmark en videreførsel af en selvstændig folkelig gymnastisk kultur, selvom begge de folkelige organisationer indoptog sportens aktiviteter i modificeret form. Idrottens Historie giver anledning til interessante hypoteser.

Der aftegner sig et billede, hvor gymnastikken bliver central. De forskellige gymnastiksystemer kobler de gymnastiske $\emptyset$ velser sammen med forskellige idealer om kropslig ypperlighed. Disse gymnastiske komplekser er i den grad velegnede til en kobling til politiske og kulturelle programmer. De sportslige aktiviteter og den sportslige ideologi er enklere. Sporten kobler det nationale og det globale på en anden facon. Det udelukker ikke en sportslig nationalisme, men koblingen til det internationale er del af denne nationalisme.

Det samme gælder forholdet til staten. I Sverige blev idrætten siden begyndelsen af 30'rne væsentlig mere afhængig af en statslig idrætspolitik inden for det socialdemokratiske koncept om Folkehjemmet Sverige. Det er klart, at en enhedsorganisation langt bedre modsvarer et statsligt ordens-koncept. Når vi i Danmark aldrig fik en enhedsorganisation, skyldes det formentlig flere ting. For det første var modstanden var for stor. Vi fik den heller ikke på det tidspunkt, hvor situationen i princippet var mest gunstig, nemlig i mellemkrigstiden. For det tredie var forholdet mellem statsmagt og idrætsorganisationer fra begyndelsen en hel anden i Danmark. For det fjerde var konstitutionen af den moderne stat forskellig i de to lande. Norge, der i 1905 fik sin selvstændighed, kunne begynde på en frisk. Den gymnastiske ideologi spillede ingen rolle. Norge var i den grad indrettet på sporten, og en statslig idrætspolitik var en naturlig sag for en ung nation. Så derfor fik de skandinaviske lande helt forskellige udviklingsforløb.

Det afdæmpede stilleje stiller egentlig det idrætspolitiske sprængstof mere klart op i vurderingen af den svenske idrætshistorie. Det gælder ikke mindst analysen og vurderingen af den Lingske gymnastiks udvikling. Men det gælder også organisationsspørgsmålet og historien om de svenske højere uddannelsesinstitutioner i idræt. Her adskiller »idrætshistorien « sig markant fra den danske selvbehandlings Sturm und Drang stil.

Somme tider egner det svenske understatement sig langt bedre til at få kampen om kroppen frem, end den danske debat.

Bogen kan varmt anbefales. Som lærebog kan afsnit af den uden problemer anvendes i gymnasier og på idrætsinstitutter. Vi har i Danmark savnet en samlet fremstilling af svensk idrætshistorie. Næste fase bliver komparative studier, ikke bare i nordisk regi. Idrætshistorien skærper nysgerrigheden. Sverige er i idrætslig henseende både utroligt tæt på og samtidig meget anderledes.

Bogen er en fremstilling og lærebog i idrætshistorie. I en vis udstrækning går den imidlertid langt udover det kronologiske og historiografiske perspektiv. Dette perspektiv gælder i bogen fortrinsvis den svenske idrætshistorie. Der er i bogen en 
vis brug af sociologisk og kulturanalytiske perspektiver. Det gælder i diskussionen i begyndelsen af kropskultur og idræt. Tilsidst i bogen bestrides det dog, at kulturbegreberne er relevante for idræt. Elias' civilisationsproces spiller en væsentlig rolle. Idrætsudøvelse, voldsafkald og aggressionskontrol bruges til at karakterisere den historiske udvikling både i antikken, middelalderen, nyere tid og det højmoderne.

Til karakteristikken af den nyeste idræt benyttes Heiniläs teser om totaliseringstendenser. Man kan ikke skrive en kort og sammenfattende historie eller lærebog uden brug af et historieteoretisk perspektiv på eet eller andet plan.

Der bliver i bogen en diskrepans mellem den ultranøgterne fremlæggelse af svensk idrætshistorie, og så de lange linier i europæisk idrætshistorie og $\mathrm{i}$ international idrætshistorie. I den svenske historie udvises der en ekstrem forsigtighed i generaliseringer og en stadig påvisning af mangler i den forskningsbaserede viden. I de globale tendenser eksisterer denne forsigtighed ikke. 